\title{
ADAPTABILITY AND PHENOTYPIC STABILITY OF SEMI-PROSTATE COWPEA GENOTYPES IN MATO GROSSO DO SUL
}

\author{
ADAPTABILIDADE E ESTABILIDADE FENOTÍPICA DE GENÓTIPOS DE FEIJÃO- \\ CAUPI SEMIPROSTRADO NO MATO GROSSO DO SUL
}

\author{
Francisco Eduardo TORRES'; Paulo Eduardo TEODORO²; Alberto CARGNELUTTI FILHO ${ }^{3}$; \\ Adriano dos SANTOS ${ }^{4}$; Maurisrael de Moura ROCHA ${ }^{5}$; Edivaldo SAGRILO ${ }^{5}$ \\ 1. Universidade Estadual de Mato Grosso do Sul, Aquidauana, MS, Brasil; 2. Universidade Federal de Viçosa, Viçosa, MG, Brasil. \\ eduteodoro@ hotmail.com; 3. Universidade Federal de Santa Maria, Santa Maria, RS, Brasil; 4. Universidade Estadual do Norte \\ Fluminense Darcy Ribeiro, Campos dos Goytacazes, RJ, Brasil; 5. Embrapa Meio-Norte, Teresina, PI, Brasil.
}

\begin{abstract}
Currently, cowpea growing covers three Brazilian regions, making essential the investigation of the magnitude of genotype $\mathrm{x}$ environment essential for choosing the best selection strategy and recommendation of cultivars. The aim of this study was to evaluate the adaptability and phenotypic stability of semi-prostate cowpea genotypes in sites from State of Mato Grosso do Sul based on different methodologies. We conducted four value of cultivation and use testing with lines and cultivars of cowpea genotypes in the years 2005 and 2006 in the municipalities of Aquidauana, Chapadão do Sul and Dourados. The experimental design was randomized complete block with 20 treatments and four replications. The grain yield data were submitted to individual and joint analysis of variance. Subsequently, data were submitted to adaptability and stability analysis by Eberhart and Russell (1966), Yates and Cochran (1938) (traditional) and Wricke (1965) methodologies. The genotypes BRS Xiquexique, TE97-304G-12, BR 17Gurguéia and MNC99-541F-15 are the most suitable for growing in Mato Grosso do Sul by combine high yield grain, adaptability and phenotypic stability.
\end{abstract}

KEYWORDS: Vigna unguiculata. Grain yield. Genotype $x$ environment.

\section{INTRODUCTION}

Cowpea [Vigna unguiculata (L.) Walp.], is an important low-cost protein source for human consumption in the North and Northeast of Brazil, where it is grown both by small farmers in subsistence conditions and small surplus volumes sale, as by medium and large producers aimed at national and international markets. However, despite Brazil is the world's third largest producer, there is permanent deficit of the product offering in the country of around 102,281 tons in the Northeast and 17,577 tons in the North, indicating that there is necessity of increased production, which translates into opportunity for producers in these regions (FREIRE FILHO et al., 2011).

The largest Brazilian cowpea producers are the states of Ceará, Piauí and Mato Grosso do Sul (FREIRE FILHO et al., 2011; TORRES et al., 2015b). In this last, its cultivation has been expanded in recent years and its adoption has intensified with cultivation in large areas by corporate farmers who uses high technology in the fields. In Mato Grosso do Sul, its cultivation is predominantly restricted to small areas, mainly by farmers coming from Northeastern region, who got settled in federal enclaves in the state and in areas belonging to indigenous communities (SANTOS et al., 2014b).

Due to the diversity of cowpea cultivation, which currently covers three Brazilian, it is very important to investigate the magnitude of genotype $\mathrm{x}$ environment interaction for choosing the best strategy selection and recommendation of cultivars (TEODORO et al., 2015 a,b). In this sense, some studies have been conducted in order to select upright and semi-prostate cowpea genotypes superior in adaptability and yield stability. Several methods are used, among them Eberhart and Russel (1966), based on linear regression, and Yates and Cochran (1938) (traditional) and Wricke (1965) methods, both based on analysis of variance (FREIRE FILHO et al., 2002; FREIRE FILHO et al., 2003; ROCHA et al., 2007; ALMEIDA et al., 2012; BARROS et al., 2013; NUNES et al., 2014).

This study aimed to evaluate the adaptability and phenotypic stability of upright and semi-prostate cowpea genotypes in sites of the State of Mato Grosso do Sul based on different methods.

\section{MATERIAL AND METHODS}

Four value for cultivation and use testing with lines and cultivars of cowpea were conducted in the years 2005 and 2006, in the municipalities of Aquidauana, Chapadão do Sul and Dourados, whose edaphoclimatic features are shown in Table 1 . Experimental design was randomized complete blocks with 20 treatments and four replications. Experimental unit consisted of four rows of $5.0 \mathrm{~m}$ in length, spaced 0.5 $\mathrm{m}$ between rows and $0.25 \mathrm{~m}$ between plants within the row. In each experimental unit, grain yield (YIE) was 
Table 1. Environments, number of genotypes, crop year, site, latitude, longitude, altitude and sowing date of semiprostate cowpea genotypes, assessed in four environments in the State of Mato Grosso do Sul, accumulated rainfall and average air temperature.

\begin{tabular}{|c|c|c|c|c|c|c|c|c|}
\hline Environment & $\begin{array}{l}\text { Number of } \\
\text { genotypes }\end{array}$ & Year & Cities & Latitude Longitude & Altitude & $\begin{array}{c}\text { Sowing } \\
\text { date }\end{array}$ & $\begin{array}{l}\text { Accumulated } \\
\text { rainfall (mm) }\end{array}$ & $\begin{array}{l}\text { Average } \\
\text { temperature } \\
\left({ }^{\circ} \mathrm{C}\right)\end{array}$ \\
\hline 1 & 20 & 2005 & Aquidauana & $22^{\circ} 01^{\prime} \mathrm{S} 54^{\circ} 05^{\prime} \mathrm{W}$ & $430 \mathrm{~m}$ & $06 / 05 / 2005$ & 83 & 24.5 \\
\hline 2 & 20 & 2005 & Chapadão do Sul & $18^{\circ} 05^{\prime} \mathrm{S} 52^{\circ} 04^{\prime} \mathrm{W}$ & $790 \mathrm{~m}$ & 06/10/2005 & 116 & 22.7 \\
\hline 3 & 20 & 2006 & Aquidauana & $22^{\circ} 01^{\prime} \mathrm{S} 54^{\circ} 05^{\prime} \mathrm{W}$ & $430 \mathrm{~m}$ & $05 / 28 / 2006$ & 121 & 23.2 \\
\hline 4 & 20 & 2006 & Dourados & $20^{\circ} 03^{\prime} \mathrm{S} 55^{\circ} 05^{\prime} \mathrm{W}$ & $147 \mathrm{~m}$ & $06 / 30 / 2006$ & 196 & 21.3 \\
\hline
\end{tabular}

Treatmentes were constituted by 18 lines (MNC99-505G-11, MNC99-507G-4, MNC99-507G-8, BRS Xiquexique, MNC99-510G-8, MNC99-510F-16, TE97-309G-18, TE97-304G-4, TE97-304G-12, TE97309G-24, MNC99-508G-1, MNC99-541F-15, MNC99541F-18, MNC99-541F-21, MNC99-542F-5, MNC99542F-7, MNC99-547F-2 and CNC x 409-11F-P2) and two cultivars (BRS Paraguaçu and BR 17-Gurguéia) of cowpea coming from the cowpea genetic breeding program from Embrapa Meio-Norte.

Grain yield data were submitted to individual analysis of variance, taking into account the effect of treatments such as fixed and the other effects as random. It was found that the relationship between the largest and smallest mean square of the individual analysis of variance of the residue did not exceed the ratio $7: 1$, thus allowing the implementation of joint analysis of trials (Banzatto and Kronka, 2006). Subsequently, the data were submitted to adaptability and stability analyzes using the Eberhart and Russell (1966), Yates and Cochran (1938) and Wricke (1965) methods, preconized by Cruz \& Regazzi (2007) for a for a smaller number of environments.

Eberhart and Russell (1966) linear regression model adoppted was $Y_{i j}=m_{i}+b_{i} I_{j}+d_{i j}+e_{i j}$, wherein $Y_{i j}$ is the average observed of the genotype $i$ in environment $\mathrm{j} ; \mathrm{m}_{\mathrm{i}}$ is the overall mean of the genotype $\mathrm{i} ; \mathrm{b}_{\mathrm{i}}$ is the regression coefficient of genotype $i ; I_{j}$ is the environmental index $j ; d_{i j}$ is the regression deviation of genotype $i$ in the environment $j ; e_{i j}$ is the mean error associated to mean. Environmental index was estimated according to the equation $I_{j}=\bar{Y}_{j}-\bar{Y}_{m}$, with $\sum_{j=1}^{n} I_{j}=0$, wherein $\bar{Y}_{m}$ is the overall mean; $\bar{Y}_{j}$ is the mean of the environment $\mathrm{j} ; \mathrm{n}$ is the number of environments.

According to Eberhart and Russell (1966 genotype adaptability was measured by the parameter $\beta_{\mathrm{li}}$, while the stability behavior was evaluated by the variance of the regression deviations $\left(\sigma_{\mathrm{di}}^{2}\right)$ and coefficient of determination ( $\left.\mathrm{R}^{2}\right)$ that, according to Cruz \& Regazzi (2007), is an auxiliary measure for assessing stability. When the $\sigma_{\text {di }}^{2}$ is significant and $\mathrm{R}^{2}$ is higher than $80 \%, \mathrm{R}^{2}$ indicates acceptable predictability.

By Yates \& Cochran (1938) method (traditional), we performed joint analysis of the trials and the subsequent unfolding of the sum of squares of environments and between genotypes and environments interaction into environments effects within genotype. Its estimator corresponds:

$$
\operatorname{to}_{(\mathrm{A} / \mathrm{Gi})}=\frac{\mathrm{r}}{(\mathrm{a}-1)}\left[\sum_{\mathrm{j}}^{\mathrm{i}=1} \mathrm{Y}_{\mathrm{ij}}^{2} \frac{\left(\mathrm{Y}_{\mathrm{i}}^{2}\right)}{\mathrm{a}}\right],
$$

wherein $Y_{i j}$ is the mean of the genotype $i(i=1,2, \ldots, g)$, in the environment $\mathrm{j}(\mathrm{j}=1,2, \ldots, \mathrm{a})$, and $\mathrm{r}$ is the number of repetitions associated to genotype.

On Wricke (1965) method, we estimated the parameter called é ecovalence $\left(\mathrm{W}_{\mathrm{i}}\right)$, obtained by partitioning the sum of squares of the genotype $x$ environment (GE), and is provided by: $\mathrm{W}_{\mathrm{i}}=\sum_{\mathrm{j}=1}^{\mathrm{n}}\left(\mathrm{Y}_{\mathrm{ij}}-\overline{\mathrm{Y}} \mathrm{i}-\overline{\mathrm{Y}}_{\mathrm{j}}+\overline{\mathrm{Y}}_{\mathrm{m}}\right)^{2}=\sum_{\mathrm{j}-1}^{\mathrm{n}}\left[(\mathrm{GE})_{\mathrm{ij}}\right]$, wherein $Y_{i j}$ is the mean of the genotype $i$ in the environment $j$; $\bar{Y} i$ is the mean of the genotype $i ; \bar{Y}_{j}$ is the mean of the environment $\mathrm{j}$; $\overline{\mathrm{Y}}_{\mathrm{m}}$ is the overall mean of the trials and $\sum_{j=1}^{n}\left[(G E)_{i j}\right]$ is the sum of squares of G×E interaction.

F test was used to assess the significance of the parameter $\sigma_{\text {di }}^{2}$ from Eberhart \& Russell (1966) method and for the obtained mean square by Yates \& Cochran (1938) method (traditional), while the t-test was used for evaluating the $\beta_{1 \mathrm{i}}$ significance from Eberhart \& Russell (1966). All analyzes were performed with the assistance of the Genes software (Cruz, 2013). 


\section{RESULTS AND DISCUSSION}

F-test from individual analysis of variation revealed significant block effect $(\mathrm{P} \leq 0.05)$ in $75 \%$ of the trials (Table 2), which shows that this design should be used in these experimental areas in order to ensure control of this source of heterogeneity. There was a
TORRES, F. E. et al.

significant difference $(\mathrm{P} \leq 0.05)$ between genotypes in all trials, suggesting the existence of genetic variability. Similar results were obtained in other studies with cowpea (ALMEIDA et al., 2012; SANTOS et al., 2014a,b; TORRES et al., 2015a; TEODORO et al., 2016).

Table 2. Summary of individual analyzes of variance for grain yield, at $\mathrm{tha}^{-1}$, of 20 semi-prostate cowpea genotypes, assessed in four environments in the State of Mato Grosso do Sul.

\begin{tabular}{lccccc}
\hline \multirow{2}{*}{ Sources of variation } & \multirow{2}{*}{ Degree of freedom } & \multicolumn{4}{c}{ Mean Square } \\
\cline { 3 - 6 } & 3 & $0.0231^{\mathrm{ns}}$ & $0.1288^{*}$ & $0.0506^{*}$ & $0.4768^{*}$ \\
\hline Block & 19 & $0.0743^{*}$ & $0.1098^{*}$ & $0.0420^{*}$ & $0.1922^{*}$ \\
Genotype & 57 & 0.0364 & 0.0296 & 0.0098 & 0.0142 \\
Error & - & 1.154 & 0.394 & 0.343 & 0.477 \\
\hline Mean & - & 16.52 & 43.66 & 28.94 & 24.93 \\
Coefficient of variation $(\%)$ & & &
\end{tabular}

*Significant at 5\% probability level by F test; ${ }^{\text {ns }}$ Not significant; Environments: A1: Aquidauana (2005); A2: Chapadão do Sul (2005); A3: Aquidauana (2006); A4: Dourados (2006).

In joint analysis (Table 3), all effects were significant $(\mathrm{P} \leq 0.05)$, which indicates contrasts between the environment and the occurrence of differential genotypes response regarding environmental effects. This can be confirmed by observing the soil and climatic characteristics of each environment (Table 1), which shows differences in altitude, latitude, longitude, climate and soil type, in addition to climatic effects such as precipitation and temperature. Similar results were obtained by Freire Filho et al. (2002, 2003), Rocha et al. (2007), Barros et al. (2013), Santos et al. (2015),
Teodoro et al. (2015a,b) and Torres et al. (2015b) who found significant differences in the genotypes, environment and genotype $\mathrm{x}$ environment interaction effects, when evaluating cowpea semi-prostate genotypes in multienvironment trials in the Mid-North region of Brazil. The existence of significant genotype $\mathrm{x}$ environment for grain yield shows that the analyses regarding stability and adaptability are appropriate, given the fact that the edaphoclimatic factors are the factors that influence the adaptability and stability of genotypes the most.

Table 3. Summary of joint analysis of variance for grain yield, at $t \mathrm{t}^{-1}$ of 20 semi-prostate cowpea genotypes, assessed in four environments in the State of Mato Grosso do Sul.

\begin{tabular}{lcc}
\hline Sources of variation & Degrees of freedom & Mean square \\
\hline Blocks/Environment & 12 & 0.1698 \\
Genotypes & 19 & $0.2256^{*}$ \\
Environments & 3 & $11.4784^{*}$ \\
Genotypes $\times$ Environments & 57 & $0.0642^{*}$ \\
Error & 228 & 0.0225 \\
\hline Mean & - & 0.5920 \\
Coefficient of variation $(\%)$ & - & 25.32 \\
\hline *Significant at 5\% probability level by F-test. & &
\end{tabular}

Based on the Eberhart and Russell (1966) method, the genotypes BRS Xiquexique, TE97-304G-12 and BR 17-Gurguéia (Table 4) were the most suitable for unfavorable environments $\left(\beta_{1 i}<1\right)$ due to their high average yield, in addition to the fact that they have high stability $\left(\sigma_{\text {di }}^{2}\right.$ close to zero) and predictability $\left(\mathrm{R}^{2}>90 \%\right)$.
Regarding favorable environments $\left(\beta_{1 \mathrm{i}}>1\right)$, the genotypes MNC99-541F-15 and TE97-309G-24 were the most recommended since they combine high average yield, and although presenting a significant $\sigma_{\text {di }}^{2}$, both have acceptable predictability $\left(\mathrm{R}^{2}>80 \%\right)$ according to Cruz and Regazzi (2007). When evaluating the 
adaptability and the stability of BR-17 Gurguéia in conjunction with other genotypes, Freire Filho et al. (2002, 2003) found specific adaptations different form the ones obtained in this study, where this cultivar obtained adaptation to favorable environments.
Nevertheless, Barros et al. (2013), when comparing the cultivars BR 17-Gurguéia and BRS Xiquexique with another group of genotypes and environments, found that they showed adaptability to unfavorable environments and high predictability.

Table 4. Average grain yield, at $\mathrm{t} \mathrm{ha}^{-1}$, and estimated parameters of adaptability and phenotypic stability of 20 semiprostate cowpea genotypes assessed in four environments in the State of Mato Grosso do Sul, by Eberhart and Russel (1966), Yates \& Cochran (1938) and Wricke (1965) methods.

\begin{tabular}{|c|c|c|c|c|c|c|c|}
\hline \multirow[b]{2}{*}{ Genotype } & \multirow{2}{*}{ Means } & \multicolumn{3}{|c|}{ Eberhart and Russel } & \multirow{2}{*}{$\begin{array}{c}\text { Yates and Cochran } \\
\text { QMAmb/Gen }\end{array}$} & \multicolumn{2}{|c|}{ Wricke } \\
\hline & & $\sigma_{\mathrm{di}}^{2}$ & $\beta_{1 \mathrm{i}}$ & $\mathrm{R}^{2}$ & & $\mathrm{~W}_{\mathrm{i}}$ & $\mathrm{W}_{\mathrm{i}}(\%)$ \\
\hline MNC99-505G-11 & 0.481 & $-0.002^{\mathrm{ns}}$ & $0.95^{\mathrm{ns}}$ & 98.17 & $0.53^{*}$ & 0.03 & 0.91 \\
\hline MNC99-507G-4 & 0.512 & $-0.003^{\mathrm{ns}}$ & $1.13^{\mathrm{ns}}$ & 98.87 & $0.74 *$ & 0.05 & 1.45 \\
\hline MNC99-507G-8 & 0.535 & $0.010^{\mathrm{ns}}$ & $0.85^{\mathrm{ns}}$ & 91.16 & $0.46^{*}$ & 0.16 & 4.34 \\
\hline BRS Xiquexique & 0.629 & $-0.003^{\mathrm{ns}}$ & $0.70^{*}$ & 97.82 & $0.28 *$ & 0.18 & 4.85 \\
\hline MNC99-510G-8 & 0.535 & $0.016^{*}$ & $0.89^{\text {ns }}$ & 88.77 & $0.51 *$ & 0.19 & 5.28 \\
\hline MNC99-510F-16 & 0.557 & $-0.005^{\mathrm{ns}}$ & $0.84^{\mathrm{ns}}$ & 99.68 & $0.40 *$ & 0.05 & 1.35 \\
\hline TE97-309G-18 & 0.390 & $0.000^{\mathrm{ns}}$ & $1.49^{*}$ & 98.79 & $1.28^{*}$ & 0.45 & 12.34 \\
\hline TE97-304G-4 & 0.592 & $0.018^{*}$ & $1.12^{\mathrm{ns}}$ & 91.99 & $0.79 *$ & 0.22 & 5.91 \\
\hline TE97-304G-12 & 0.705 & $0.010^{\mathrm{ns}}$ & $0.84^{\mathrm{ns}}$ & 90.44 & $0.45^{*}$ & 0.17 & 4.73 \\
\hline TE97-309G-24 & 0.625 & $0.016^{*}$ & $1.39 *$ & 94.96 & $1.16^{*}$ & 0.43 & 11.80 \\
\hline MNC99-508G-1 & 0.719 & $0.020^{*}$ & $0.76^{*}$ & 83.15 & $0.40 *$ & 0.30 & 8.22 \\
\hline MNC99-541F-15 & 0.630 & $-0.003^{\text {ns }}$ & $1.04^{\mathrm{ns}}$ & 98.97 & $0.63^{*}$ & 0.02 & 0.61 \\
\hline MNC99-541F-18 & 0.678 & $0.013^{*}$ & $0.96^{\mathrm{ns}}$ & 91.66 & $0.58^{*}$ & 0.15 & 4.04 \\
\hline MNC99-541F-21 & 0.466 & $-0.006^{\mathrm{ns}}$ & $0.86^{\mathrm{ns}}$ & 99.94 & $0.43 *$ & 0.03 & 0.91 \\
\hline MNC99-542F-5 & 0.801 & $-0.004^{\mathrm{ns}}$ & $0.87^{\mathrm{ns}}$ & 98.82 & $0.44^{*}$ & 0.04 & 1.22 \\
\hline MNC99-542F-7 & 0.548 & $-0.001^{\mathrm{ns}}$ & $1.37 *$ & 98.81 & $1.09 *$ & 0.27 & 7.47 \\
\hline MNC99-547F-2 & 0.427 & $-0.001^{\mathrm{ns}}$ & $0.90^{\mathrm{ns}}$ & 97.33 & $0.48^{*}$ & 0.06 & 1.53 \\
\hline BRS Paraguaçu & 0.801 & $0.046^{*}$ & $0.88^{\mathrm{ns}}$ & 76.12 & $0.58^{*}$ & 0.44 & 12.07 \\
\hline BR 17-Gurguéia & 0.723 & $0.006^{\mathrm{ns}}$ & $1.13^{\mathrm{ns}}$ & 95.95 & $0.76^{*}$ & 0.12 & 3.34 \\
\hline CNCx409-11F-P2 & 0.487 & $0.029 *$ & $1.04^{\mathrm{ns}}$ & 87.11 & $0.71 *$ & 0.28 & 7.63 \\
\hline
\end{tabular}

*Significant at $5 \%$ probability level by $\mathrm{F}$ test for $\sigma_{\mathrm{di}}^{2}$ and $\mathrm{QMAmb} / \mathrm{Gen}$ and by t-test for the $\beta_{\mathrm{li}}$; parameters. ${ }^{\text {ns }}$ not significant.

By the Yates and Cochran (1938) (traditional) method, the measure of stability corresponds to the variation of environments within each genotype, the genotype that has a lower mean square being considered more stable. Thus, the BRS Xiquexique, genotype recommended for unfavorable environments by the Eberhart and Russell (1966) method, is more stable according to the traditional method, besides obtaining above overall yield mean of testing. These results confirm those obtained by Cargnelutti Filho et al. (2007, 2009), who, when comparing methods for estimating the adaptability and stability of maize genotypes, found that genotypes indicated by the traditional method have greater stability, being more suitable to unfavorable environments by the Eberhart and Russell (1966) method.

The stability of each genotype in the environments whas evaluated by the Wricke (1965) method, where the most stable genotype is the one that has the lowest Wi index (\% ecovalence), which represents the relative contribution of each genotype in the sum of squares of the genotype $\mathrm{x}$ environment in the analysis of variance. Thus, amongst the evaluated genotypes, MNC99-541F-15 proved to be the most stable, in addition to the fact that its grain yield is above the overall average of trials and it is also recommended by the Eberhart and Russell (1966) method for favorable environments. Cargnelutti Filho et al. $(2007,2009)$ also assess the association between these methods for indicating the most productive maize genotypes.

It is worth mentioning that genotypes BRS Xiquexique, TE97-304G-12, BR 17-Gurguéia and MNC99-541F-15 showed good phenotypic stability, estimated by the Yates and Cochran (1938) (traditional) method and the Wricke (1965) method, which shows good agreement between these methods. Moreover, these genotypes were recommended by the Eberhart and Russell (1966) method, disagreeing with the inference 
made by Cruz and Regazzi (2007) that genotypes with regular behavior in a range of environments are, usually, less productive.

\section{CONCLUSIONS}

The genotypes BRS Xiquexique, TE97-304G12, BR 17-Gurguéia and MNC99-541F-15 are the most suitable for growing in the State of Mato Grosso do Sul, since it combine high grain yield, adaptability and phenotypic stability.

RESUMO: Atualmente o cultivo do feijão-caupi abrange três regiões do Brasil, o que torna a investigação da magnitude da interação genótipo $\times$ ambiente imprescindível para a escolha da melhor estratégia de seleção e recomendação de cultivares. $\mathrm{O}$ objetivo deste trabalho foi avaliar a adaptabilidade e estabilidade fenotípica de genótipos de feijão-caupi de porte semiprostrado em locais do Estado de Mato Grosso do Sul com base em diferentes metódos. Foram conduzidos quatro ensaios de valor de cultivo e uso com linhagens e cultivares de genótipos de feijão-caupi nos anos de 2005 e 2006, nos municípios de Aquidauana, Chapadão do Sul e Dourados. O delineamento experimental utilizado foi o de blocos completos casualizados, com 20 tratamentos e quatro repetições. Os dados de produtividade de grãos foram submetidos a análises de variância individual e conjunta. Posteriormente, foram realizadas análises de adaptabilidade e estabilidade por meio dos métodos de Eberhart e Russell (1966), Yates e Cochran (1938) (tradicional) e de Wricke (1965). Os genótipos BRS Xiquexique, TE97-304G-12, BR 17-Gurguéia e MNC99-541F-15 são os mais indicados para o cultivo no Estado de Mato Grosso do Sul, pois aliam alta produtividade de grãos, adaptabilidade e estabilidade fenotípica.

PALAVRAS-CHAVE: Vigna unguiculata. Produtividade de grãos. Genótipo $\times$ ambiente.

\section{REFERENCES}

ALMEIDA, W. S.; FERNANDES, F. R. B.; TEÓFILO, E. M.; BERTINI, C. H. C. M. Adaptability and stability of grain yield in cowpea under different biometrics. Revista Brasileira de Agrociência, pelotas, v. 18, p. 221-228, 2012.

BANZATTO, D. A.; KRONKA, S. N. Experimentação agrícola. Jaboticabal: FUNEP, 2006. 237 p.

BARROS, M. A.; ROCHA, M. M.; GOMES, R. L. F.; SILVA, K. J. D.; NEVES, A. C. Adaptabilidade e estabilidade produtiva de feijão-caupi de porte semiprostrado. Pesquisa Agropecuária Brasileira, Brasília, v. 48, p. 403-410, 2013. http://dx.doi.org/10.1590/S0100-204X2013000400008

BARROSO, L. M. A.; TEODORO, P. E.; NASCIMENTO, M.; TORRES, F. E.; SANTOS, A.; CORREA, A. M.; SAGRILO, E.; CORRÊA, C. C. G.; SILVA, F. A.; CECCON, G. Bayesian approach increases accuracy when selecting cowpea genotypes with high adaptability and phenotypic stability. Genetics and Molecular Research, Ribeirão Preto, v. 15, n. 1, gmr.15017625, 2016. http://dx.doi.org/10.4238/gmr.15017625

CARGNELUTTI FILHO, A.; PERECIN, D.; MALHEIROS, E. B.; GUANDAGNIN, J. P. Comparação de métodos de adaptabilidade e estabilidade relacionados à produtividade de grãos de cultivares de milho. Bragantia, Campinas, v. 66, p. 571-578, 2007. http://dx.doi.org/10.1590/S0006-87052007000400006

CARGNELUTTI FILHO, A.; STORCK, L.; RIBOLDI, J.; GUANDAGNIN, J. P. Associação entre métodos de adaptabilidade e estabilidade em milho. Ciência Rural, Santa Maria, v. 39, p. 340-347, 2009.

http://dx.doi.org/10.1590/S0103-84782008005000080

CRUZ, C. D; REGAZZI, A. J. Modelos biométricos aplicados ao melhoramento genético. Viçosa: UFV, 2007. 480 p.

EBERHART, S. A.; RUSSELL, W. A. Stability parameters for comparing varieties. Crop Science, Madson, v. 6, p. 3640, 1966. 
FREIRE FILHO, F. R.; RIBEIRO, V. Q.; ROCHA, M. M.; DAMASCENO-SILVA, K. J.; NOGUEIRA, M. S. R.; RODRIGUES, E. V. Feijão-caupi no Brasil: produção, melhoramento genético, avanços e desafios. Teresina: Embrapa Meio-Norte, 2011. 84 p. http://dx.doi.org/10.1590/S0100-204X2003000500006

FREIRE FILHO, F. R.; RIBEIRO, V. Q.; ROCHA, M. M.; LOPES, A. C. A. Adaptabilidade e estabilidade da produtividade de grãos de genótipos de caupi enramador de tegumento mulato. Pesquisa Agropecuária Brasileira, Brasília, v. 38, p. 591-598, 2003.

FREIRE FILHO, F. R.; RIBEIRO, V. Q.; ROCHA, M. M.; LOPES, A. C. A. Adaptabilidade e estabilidade da produtividade de grãos de linhagens de caupi de porte enramador. Revista Ceres, Viçosa, v. 49, p. 383-393, 2002.

NUNES, H. F.; FREIRE FILHO, F. R.; RIBEIRO, V. Q.; GOMES, R. L. Grain yield adaptability and stability of blackeyed cowpea genotypes under rainfed agriculture in Brasil. African Journal of Agricultural Research, Punjab, v. 9, n. 2, p.255-261, 2014. http://dx.doi.org/10.5897/AJAR212.2204

ROCHA, M. M.; FREIRE-FILHO, F. R.; RIBEIRO, V. Q.; CARVALHO, H. W. L.; BELARMINO-FILHO, J.; RAPOSO, J. A. A.; ALCÂNTARA, J. P.; RAMOS, S. R. R.; MACHADO, C. F. Adaptabilidade e estabilidade produtiva de genótipos de feijão-caupi de porte semiereto na região Nordeste do Brasil. Pesquisa Agropecuária Brasileira, Brasília, v. 42, n. 9, p. 1283-1289, 2007. http://dx.doi.org/10.1590/S0100204X2007000900010

SANTOS, A.; CECCON, G.; RODRIGUES, E. V.; TEODORO, P. E.; MAKIMO, P. A.; ALVES, V. B.; SILVA, J. F.; CORREA, A. M.; ALVAREZ, R. C. Adaptability and stability of cowpea genotypes to Brazilian Midwest. African Journal of Agricultural Research, Punjab, v. 10, p. 3901-3908, 2015.

http://dx.doi.org/10.5897/AJAR2015.10165

SANTOS, J. A. S.; TEODORO, P. E.; CORREA, A. M.; SOARES, C. M. G.; RIBEIRO, L. P.; ABREU, H. K. A. Desempenho agronômico e divergência genética entre genótipos de feijão-caupi cultivados no ecótono Cerrado/Pantanal. Bragantia, Campinas, v. 73, p. 377-382, 2014a. http://dx.doi.org/10.1590/1678-4499.0250

SANTOS, J. A. S.; SOARES, C. M. G.; CORRÊA, A. M.; TEODORO, P. E.; RIBEIRO, L. P.; ABREU, H. K. A. Agronomic performance and genetic dissimilarity among cowpea (Vigna unguiculata (L.) Walp.) genotypes. Global Advanced Research Journal of Agricultural Science, Sapele, v. 3, n. 8, p. 271-277, 2014b.

TEODORO, P. E.; BARROSO, L. M. A.; NASCIMENTO, M.; TORRES, F. E.; SAGRILO, E.; SANTOS, A.; RIBEIRO, L. P. Redes neurais artificiais para identificar genótipos de feijão-caupi semiprostrado com alta adaptabilidade e estabilidade fenotípicas. Pesquisa Agropecuária Brasileira (Online), Brasília, v. 50, p. 10541060, 2015a.

TEODORO, P. E.; NASCIMENTO, M.; TORRES, F. E.; BARROSO, L. M. A.; SAGRILO, E. Perspectiva bayesiana na seleção de genótipos de feijão-caupi em ensaios de valor de cultivo e uso. Pesquisa Agropecuária Brasileira (Online), Brasília, v. 50, p. 878-885, $2015 \mathrm{~b}$.

TEODORO, P. E.; TORRES, F. E.; SANTOS, A.; CORRÊA, A. M.; NASCIMENTO, M.; BARROSO, L. M. A.; CECCON, G. Measurements of experimental precision for trials with cowpea (Vigna unguiculata L. Walp.) genotypes. Genetics and Molecular Research, Ribeirão Preto, v. 15, n. (1), gmr.15017625, 2016. http://dx.doi.org/10.4238/gmr.15027991

TORRES, F. E.; SAGRILO, E.; TEODORO, P. E.; RIBEIRO, L. P.; CARGNELUTTI FILHO, A. Número de repetições para avaliação de caracteres em genótipos de feijão-caupi. Bragantia, Campinas, v. 74, p. 161-168, 2015a. http://dx.doi.org/10.1590/1678-4499.0393 
TORRES, F. E.; TEODORO, P. E.; SAGRILO, E.; CORREA, A. M.; CECCON, G. Interação genótipo x ambiente em genótipos de feijão-caupi semiprostrado via modelos mistos. Bragantia, Campinas, v. 74, p. $255-$ 260, 2015. http://dx.doi.org/10.1590/1678-4499.0099

WRICKE, G. Zur berechnung der okovalenz bei sommerweizen und hafer. Zeitschrift Pflanzenzuchtg, Berlin, v. 52, p. 127-138, 1965.

YATES, F.; COCHRAN, W. G. The analysis of group of experiments. Journal of Agriculture Science, Cambridge, v. 28, p. 556-580, 1938. http://dx.doi.org/10.1017/S0021859600050978 